\title{
WIDENING THE BREADTH OF KNOWLEDGE DIFFUSION AMONG NIGERIAN EMPLOYEES: THE UPSIDES OF GLOBALIZATION
}

\author{
Onodugo Vincent A. ${ }^{1}$--- Nwoji Stanley C. ${ }^{2}$ \\ ${ }^{\prime}$ Department of Management, University of Nigeria, Enugu Campus, Nigeria \\ ${ }^{2}$ Trinity Washington University, Michigan Avenue, NE Washington, United States of America
}

\begin{abstract}
Many scholars from the developing world argue that globalization is a weapon of imperialism used to perpetuate the income and welfare gap between developing and developed countries. This study joins an emerging stream of studies calling for a holistic re-examination of the impact of globalization on developing countries to understand both the positive and negative contributions instead of have a one-sided view of globalization. Employing a quantitative design with a survey strategy, data for this study was collected from 130 human resources personnel across six multinational firms spanning: oil, banking, and manufacturing sectors of the Nigerian economy. Inferential analysis of collected data found significant positive contributions of globalization towards personnel training and development. In particular, findings show that globalization has increased the frequency and methods of trainings, increased use of e-trainings and certifications, and uniform design of training programmes across the subsidiaries of MNCs globally. All these were found to reduce the physical incidence of personnel going abroad to study reducing both brain-drain and expenses to domestic companies and governments.
\end{abstract}

Keywords: Globalization, Human resources, Development and training, Multinationals.

Received: 17 June 2013/ Revised: 11 July 2013/ Accepted: 13 July 2013/ Published: 16 July 2013

\section{INTRODUCTION}

Quite a number of studies and literature on globalization, especially as it impacts on the socio-economic welfare of developing countries, have inadvertently centered on the downsides of globalization (Rodney, 1972; Khor, 2003; Aimiuwu, 2004; Soludo, 2008). The extent of this lopsidedness is supported by the sheer fact that the book on "Globalization and Its Discontents" (Stiglitz, 2003) became an instant bestseller. Understandably, the widening gap in terms of socioeconomic development between developed countries and those that are yet to develop since the advent of globalization seems to justify this perception. 
This prevailing notion notwithstanding, certain recent developments have made it imperative to widen the dimensions of the debate and explore all the sides of the coin. One factor that is pushing for this shift is the apparent consensus among scholars that globalization and the technological changes that brought it about, are forces that have and will continue to impact on the economic and social fabrics of the various nations (Ohamae, 1990; Thurow, 1992; Lipsey, 1993; Chaykowski, 2002), and for the most part, is irreversible (Wolfensohn, 2002; Adei, 2004). The implication is that if there is nothing that can be done to reverse this phenomenon, then it makes sense to find ways to make the most of it.

A paradigm shift in globalization studies has been catalyzed by remittances to developing countries, an unintended outcome that is fast-tracking the development of most developing countries including Nigeria. Available data show that albeit, African remittances remain relatively small in proportion to global remittances flow; it has however, exhibited strong growth in the last 20 years, from only US $\$ 1.9$ billion in 1990 to $\$ 4.6$ billion in 2000 and $\$ 10.045$ billion as at 2010 (Lindely, 2008; World Bank, 2011). The Nigerian statistics are even more interesting and significant. According to the World Bank (2008), Nigeria is the highest remittance recipient nation in Africa, providing home for nearly $50 \%$ of the inflow. Data on remittance inflows in Nigeria reveal that it exceeds Foreign Direct Investment (FDI), portfolio inflows, and non-oil exports. Foreign Direct Investments stand at 3.2 percent, Portfolio Inflows at 0.6 percent, and Non-Oil Exports at 0.7 percent of GDP as at 2007 (CBN, 2007; Harnendez-Coss and Bun, 2007; Orozco and Mills, 2008). The World Bank expects continued growth in remittance flows going forward, by 7.3 per cent in 2012, 7.9 per cent in 2013 and 8.4 per cent in 2014.

Non-monetary remittances are gains of globalization that have not been given adequate attention (Bartram, 2011; Rivera and Reyes, 2011; Robles and Oropesa, 2011; Boateng and Oppon-Boakye, 2013). Emigrants have transferred non-monetary remittances like new skills, new knowledge, new technologies, entrepreneurship, new political systems, and so on. Globalization has offered developing nations both monetary and non-monetary remittances.

Given the above gains, it is pertinent that scholars and leaders of developing countries shift from demonizing globalization as an imperialistic tool of the West, to taking an empirical assessment of globalization, which could lead to retaining and utilizing its positive contributions. This will increase chances of formulating and implementing relevant policies that will either maximize the opportunities it presents or minimize the challenges and threats that flow from it.

This study is undertaken to specifically investigate the extent to which globalization has impacted training and knowledge acquisitions among employees in Nigerian firms. Specifically it seeks to assess the extent to which globalization has impacted on the following aspects of human development: 1)the frequency of human resource development; 2) the incidence of oversea training; 3) increased methods used in training and developments including on-the-job etrainings; 4) acceptance of e-learning certification and 5) uniformity in design and training content among organizations in the different parts of the globe. 
This study utilized a quantitative design with a survey strategy. Quantitative data was collected from 130 human resources personnel across six multinational firms spanning oil, banking and manufacturing sectors of the Nigerian economy using close-ended questionnaires.

\subsection{Brief Review of Related Literature}

There is little doubt that one of the challenges of globalization is the heightened competition among global firms that defy the physical boundaries that hitherto hinder market reach during pre-globalized era. Consequently, firms do all within their reach to shore up their competitiveness. Among all the available options for increasing firm's capacity and competitiveness, continuously developing and exploiting employee knowledge assets seems to have an edge over others (Appelbaum and Batt, 1994; Locke and Kochan, 1995; Bae and Rowley, 2002; Herstad and Brekke, 2011). This is because strategies that focus on natural and technological resources will certainly be unsustainable.

Study by Kale and Little (2010) on the development of Indian pharmaceutical industry, in their struggle to increase their global competitiveness, revealed that, as a last resort, they (pharmaceutical firms) had to employ Indian scientists that studied or worked abroad to tap from their repertoire of gained knowledge. The underlying assumption, which seems to be at the core of the technology transfer strategy of most Asian nations is that human mobility within or across firms play a very important role in transferring knowledge, skills and competencies.

Chaykowski (2002), in his study on the impact of globalization on the Canadian Labour Policy, observes rightly that much of the literature on labour and employment relationships in the "new economy" focused on the shift towards higher skills. This quest for higher skills is fuelled by competition and technological changes. New communication technologies, particularly the internet, have provided electronic access to education through distance learning internationally (Stilwell et al., 2004). Essentially the global competition for skilled labor and considerably high return for highly skilled individuals have tended to provide individual motivation for skill acquisition (Dasgupta, 2009).

Another compelling reason behind massive quest for knowledge diffusion is the fact that a major feature of globalization is to extend production activities to areas where labour is cheap so as to produce and sell at competitive prices. This trend has inextricably heightened the need to train host country nationals to acquire the requisite skills to be productive (Farazmand, 1999). This is especially the case as it is practically difficult and extremely costly and counter-productive to extensively engage expatriates to do the work. All these have made acquisition of modern skills and production competencies imperative. It is this stage of globalization that Steers and Nardon (2006), call "achieving complete globalization". During this phase, "managers do not think themselves as American or Japanese or German. Rather they think themselves and their company as a truly global enterprise that transcends borders and competes everywhere. Such companies source people, raw materials and technology where they are best and cheapest." 
Bernardine (2003) identifies four possible models/ strategic approaches in international human development activities, they are: a) Ethnocentric model: Under this model recruitment, training and deployment of personnel are done from the headquarters. The belief is that if it is decentralized it may compromise the quality of service delivery and competitiveness (Bird et al., 1998) Polycentric Model: This model is the flip side of the ethnocentric model. It permits recruitments and deployments of staff to be done competitively from the local labour market. This approach is cheaper and more adaptable to local conditions. The only challenge is that it limits the chances of technology transfer. c) Geocentric Model: This model tries to remove the boundaries and separating lines between the parent company and the subsidiaries scattered all over the globe. It strives to integrate its businesses with the relationships based on collaboration and mutual reciprocity. Under this model, the organization begin to see itself as having a global workforce that can be deployed and utilized in a variety of ways throughout the world. Key positions tend to be filled by the most qualified individuals regardless of nationality. Regiocentric Model: This is a modified version of geocentric model. The main difference is in scope; while the latter is global in scope; the former is regional. In other words, Africans will manage African subsidiaries, just as Europeans will manage European subsidiaries. To function properly, there is usually a strong regional headquarters that is vested with the power and authority to manage its operations in the particular region. These regional headquarters integrate and collaboratively manage the subsidiaries within its region. The only challenge is that there is usually limited flow between the regions and the global headquarters. In some cases some use this model as a prelude and preparation to full-scale geocentric model

It is important to note that within the contextual needs of developing countries any model chosen must strike a balance between maximizing its huge labour potential and providing opportunities for technology transfer. A critical look at the models presented above shows a clear trade-off between the twin goals of maximizing labour potentials of the host countries and technology transfer. For instance, ethnocentric and geocentric models increase the chances of technology transfer while minimizing the chances of utilizing local labour. While the regiocentric and polycentric models maximize the use of labour and reduce chances of technology transfer. The best strategy is for developing countries to initiate policies that will achieve a proper mix between the two goals.

It is pertinent to note that there are factors that affect the extent to which various regions endowed with surplus cheap labour benefit from this trend of outsourcing production activities to nations and regions where labour and raw materials are cheap. Across the various regions considered among developing nations, countries within the Asian Pacific rim seems to be enjoying more FDIs than countries in South American and African continents. There are also intraregional country variations in investment climate suitability. For instance in Sub-Saharan Africa, countries like South Africa, Kenya and Ghana were ranked better than Nigeria in terms of ease of doing business (World Bank Doing Business in Nigeria, 2008). Some of the factors that 
determine preferences for choosing areas of investment are political stability, safety of property, ease in land acquisition, the effectiveness of the legal system, etc.

\section{METHODOLOGY}

This study made use of quantitative design with a survey strategy. Data was sourced from both primary and secondary sources. Personnel (especially those from the human resources department) from the sampled firms were the major sources of primary data while reports of previous studies and literature were the source of secondary data. A sample size of 130 human resource personnel was derived from six selected multinational firms from oil, banking and manufacturing sectors of the Nigerian economy. Data were collected using close-ended questionnaire. The interview was mainly carried out on the human resources managers of these organizations, while the questionnaires were randomly administered to personnel from the human resources department. The analysis of data, interpretation and test of hypotheses was done with SPSS.

\section{HYPOTHESIS FORMULATION}

This is guided by the following hypothesis:

$\mathrm{H}_{1}$ : Globalization factors have strong influence on methods of human resources skill development.

The null hypothesis can be stated thus:

$\mathrm{H}_{0}$ : $\quad$ Globalization forces do not have strong influences on methods of human resources skill development.

\section{RESULTS}

Data analyses focused on the key aspects of job based-knowledge acquisition, which constituted the specific objectives of this study. They are:

a. Globalization and the frequency of staff training.

b. The influence of globalization on training of staff abroad;

c. Globalization and variety of methods including on-the-job-e-trainings;

d. The extent to which globalization has led to the acceptance of e-learning training and certification;

e. Globalization and uniform training programmes among the branches of multinational organizations investigated;

The resulting data on these areas are presented below: 
Fig-1.1.Impact of Globalization on the Frequency of Training and Development

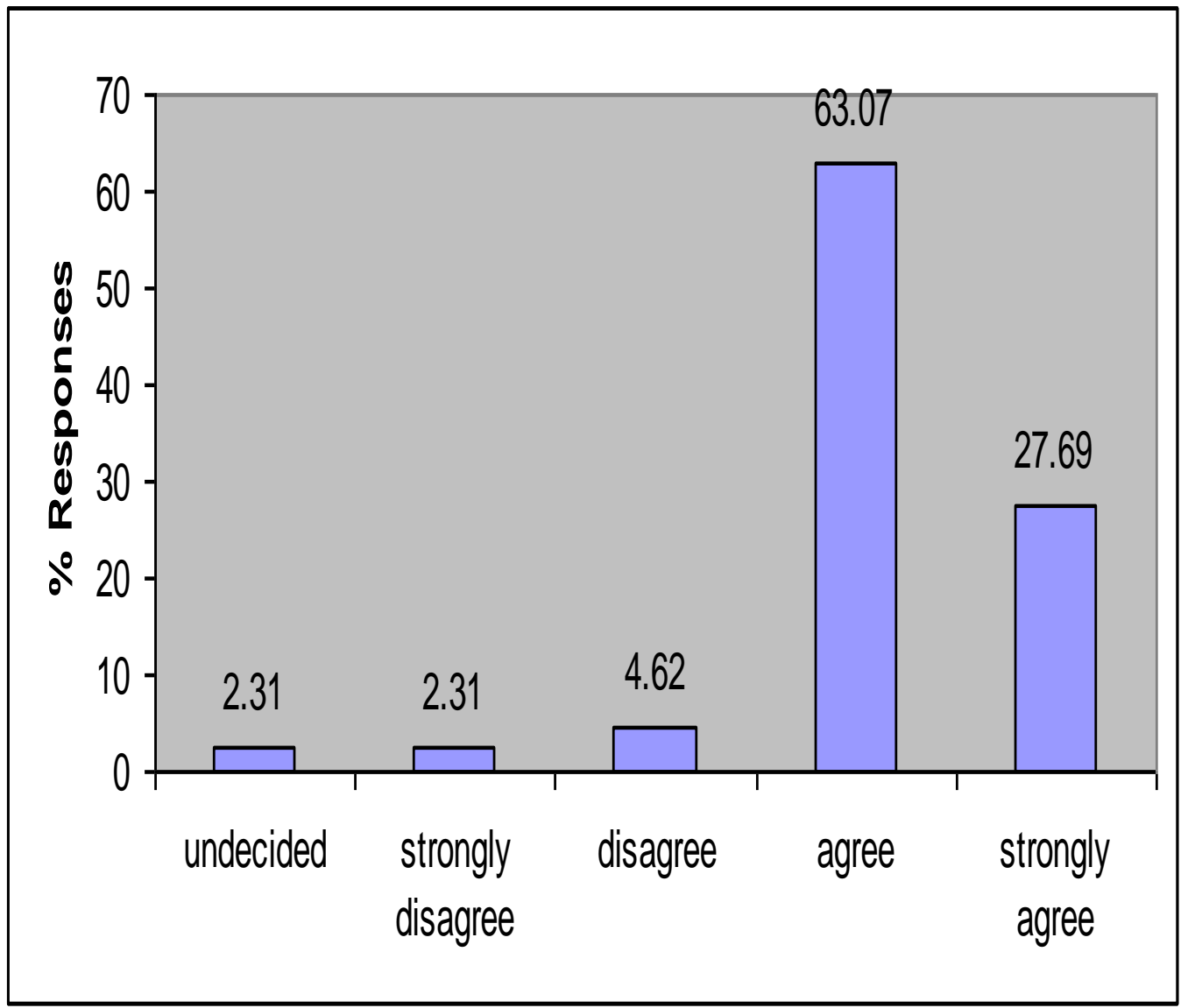

Source: Field Survey

The data in Figure 1.1 above show that globalization has led to increase in the frequency of training and development in Nigerian organizations. This is supported by about $91 \%$ of the respondents who either agreed or strongly agreed. The rest $9 \%$ either disagreed or were undecided. 
Fig-1.2.Globalization and Increase in Oversea Training

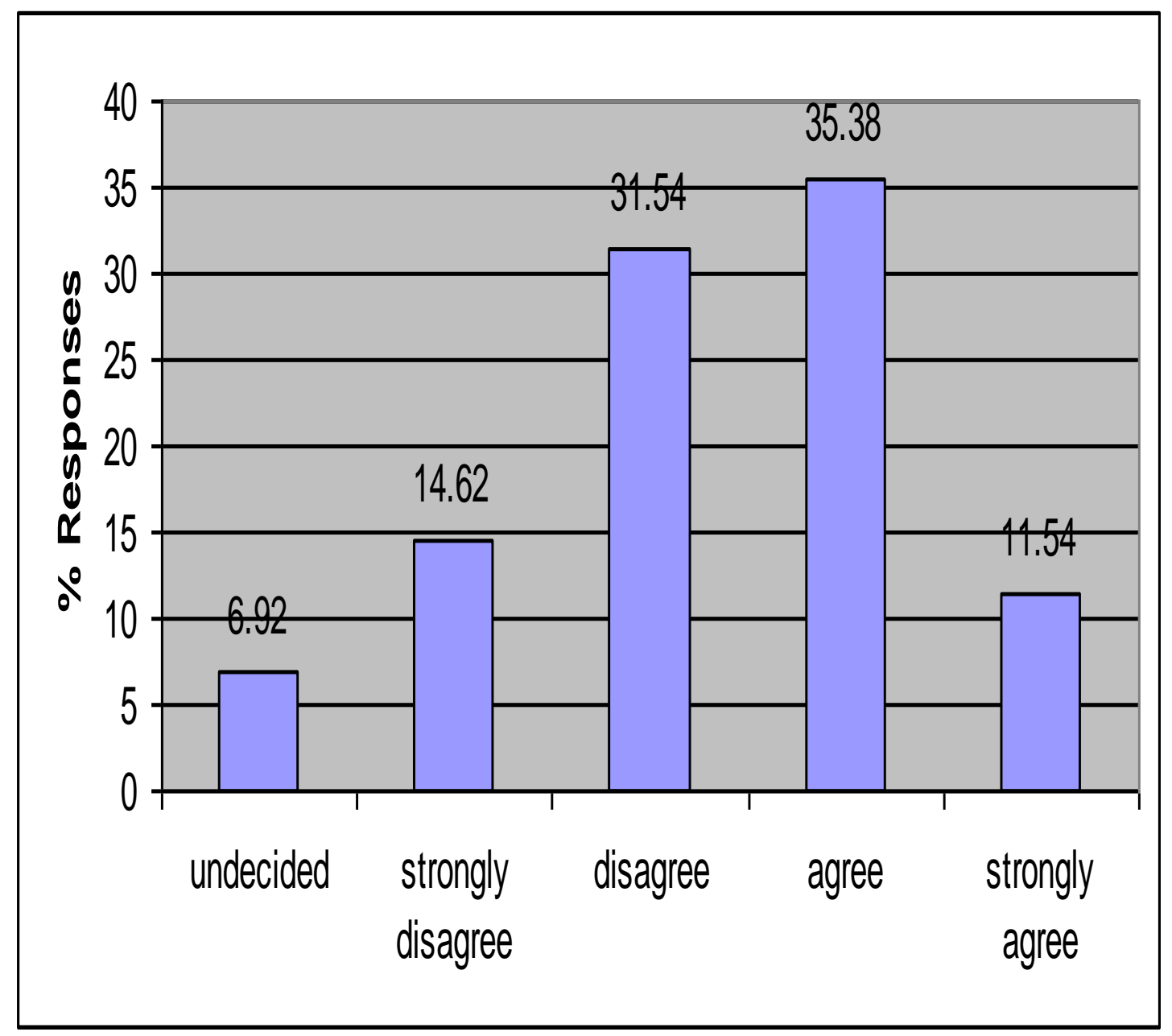

The data in Figure 1:2 above do not give a clear direction as to whether globalization has increased oversea training or not. A total of about $47 \%$ agreed or strongly agreed, while approximate $46 \%$ disagreed or strongly disagreed. The rest $7 \%$ were undecided. Except for sector variations, we cannot conclude that globalization has led to more oversea training. 
Fig-1.3. Globalization and Increase in Variety of Training Methods Including E-trainings

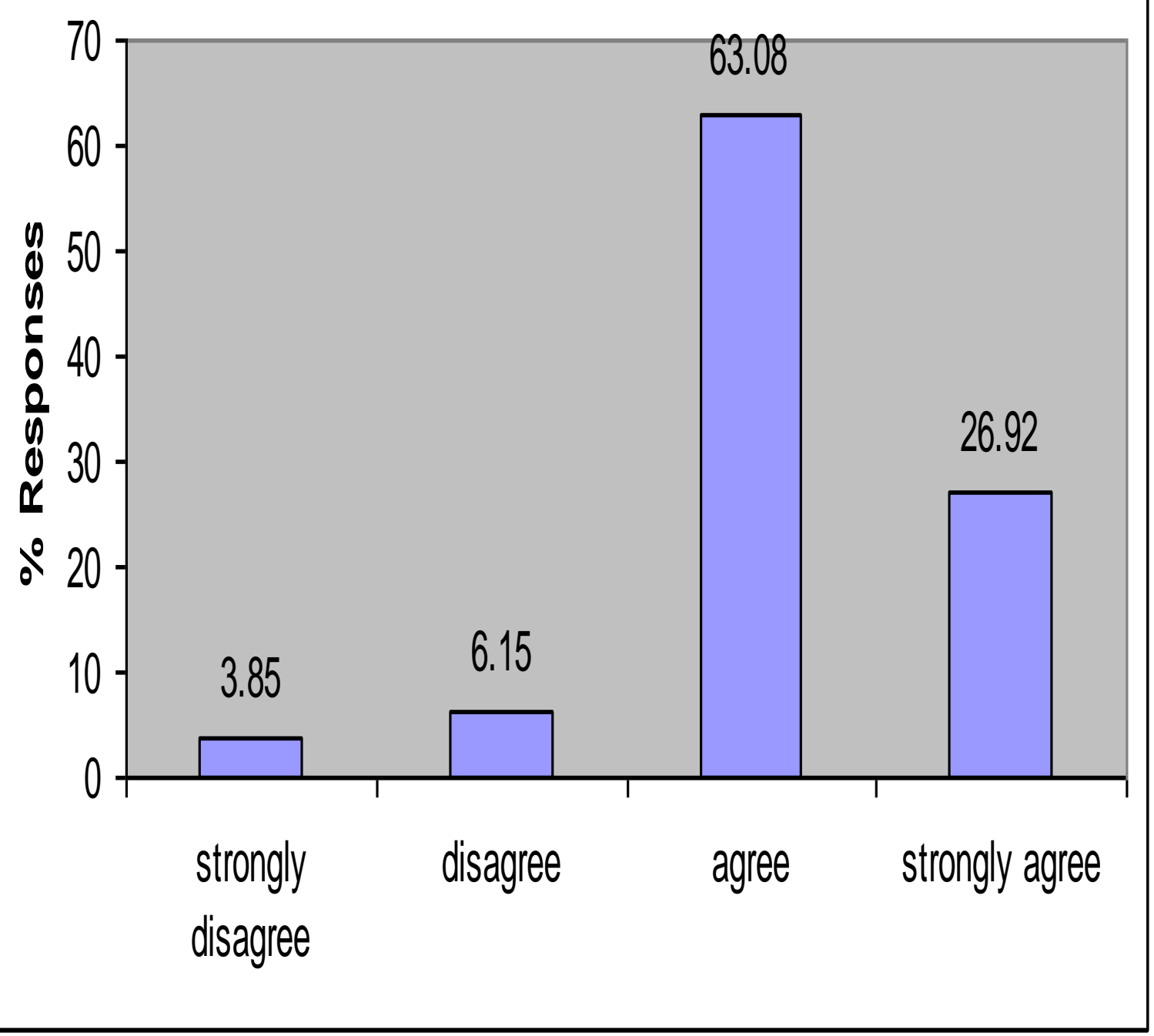

Source: Field Survey

The data in Figure 1.3 above clearly show that globalization has generally increased the variety of training methods including the use of e-trainings. Approximate $90 \%$ of the respondents either agreed or strongly agreed, while the rest $10 \%$ disagreed or strongly disagreed. 
Fig-1.4. Globalization and Increase in Acceptance of E-Learning Training and Certification

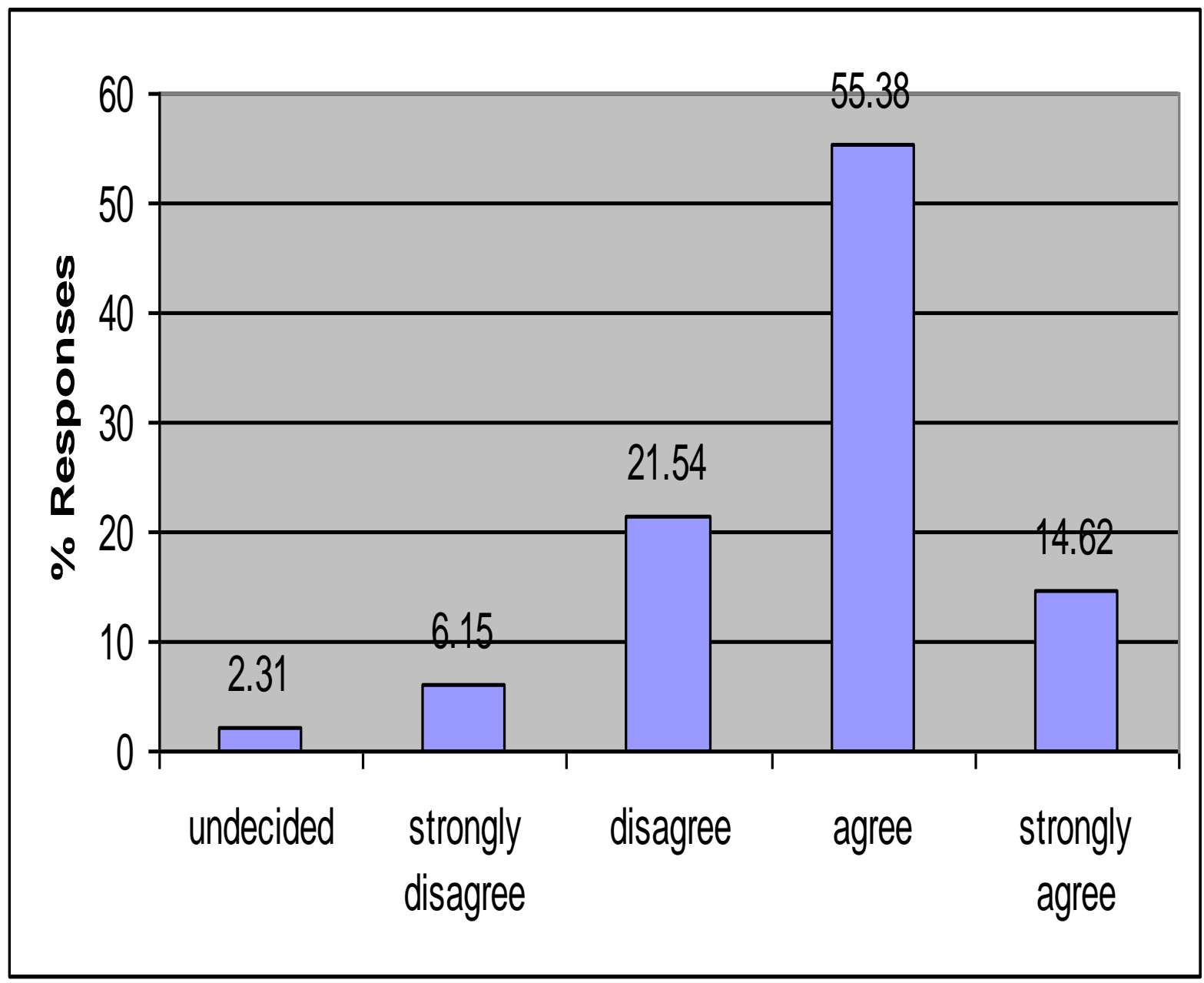

Source: Field Survey

The data in Table Figure 1.4 above show that globalization has led to increased acceptance of elearning trainings and certifications. This is supported by approximate $70 \%$ of the respondents who agreed or strongly agreed. About $28 \%$ disagreed while the rest $2 \%$ were undecided. 
Fig-1.5.Globalization and Uniform Design of Training Programmes

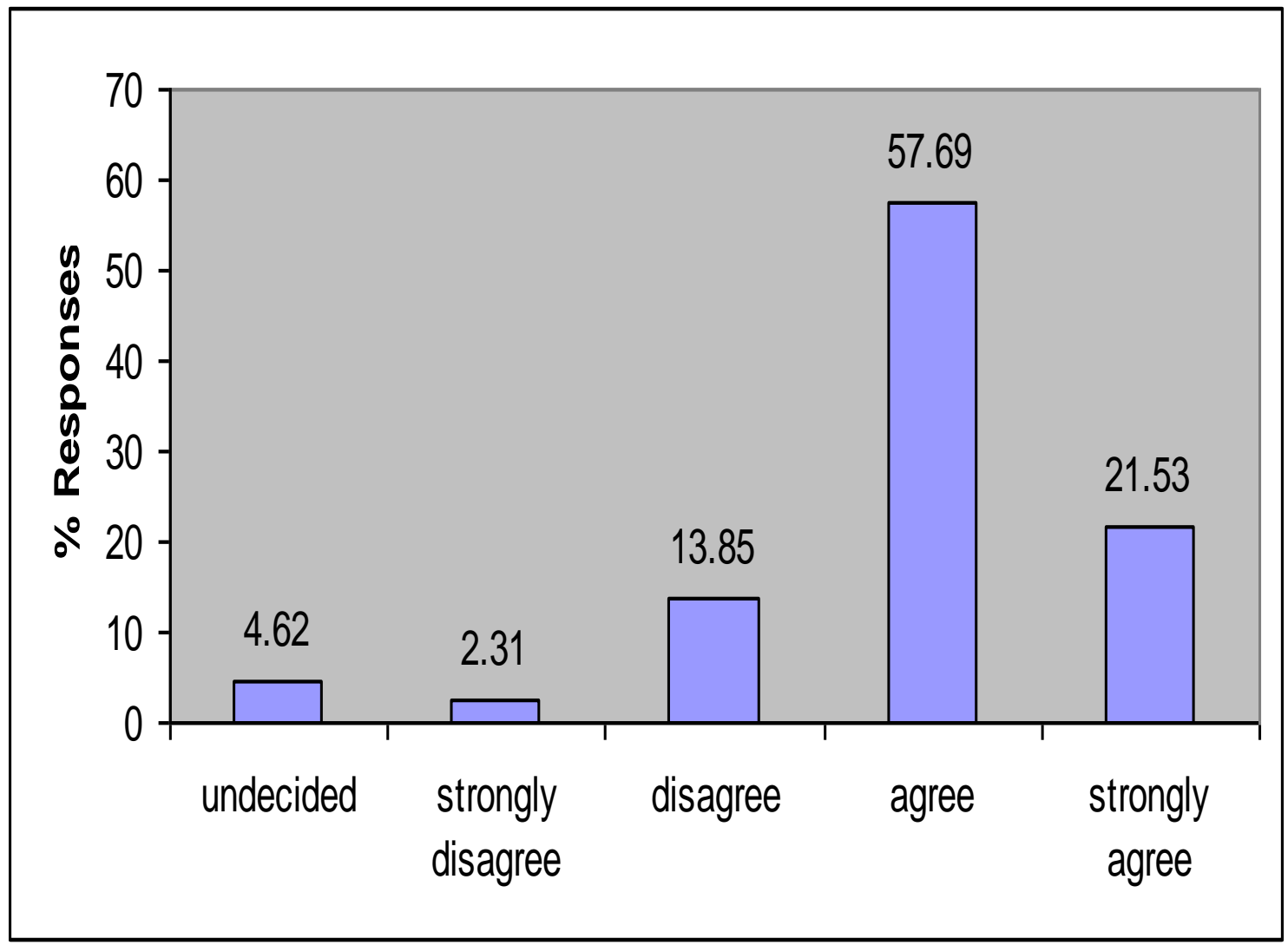

Source: Field Survey

The data displayed in Figure 1:5 above show that globalization has led to uniform training programmed across the branches of most multinational organizations. Approximately $79 \%$ of the respondents agreed or strongly agreed, about 16\% disagreed and approximately 5\% were undecided.

\section{Test of Hypothesis}

H1: Globalization factors have strong influence on methods of human resources skill development.

The null hypothesis can be stated thus:

Ho: Globalization forces do not have strong influences on methods of human resources skill development.

Data for the test of this hypothesis was got from responses displayed in figures 1.1 to 1.5 of the preceding section. In order to test the above hypothesis, t-test was employed. The obtained responses on factors of globalization were compared with a value of 3, which represents the mean of responses on a five-point scale $(5,4,3,2,1)$. The obtained factor-by-factor values as well as the aggregate are shown in table 4.1 below. The obtained t- values reveal that all the globalization 
factors, as given by the study, have strong influence on methods of human resources skill development at $\mathrm{P} \leq 0.05$. Given this result, we reject the null hypothesis and accept the alternate hypothesis meaning that globalization have strong influence on methods of human resources skill development.

Table-1.T-Values for Test of Hypothesis

\begin{tabular}{|c|c|c|c|c|c|}
\hline Question item & Mean & $\begin{array}{c}\text { Std. } \\
\text { Deviation }\end{array}$ & $\mathrm{t}$ & df & $\begin{array}{l}\text { Sig. }(2- \\
\text { tailed) }\end{array}$ \\
\hline $\begin{array}{l}\text { Globalization has increased the } \\
\text { frequency and techniques for staff } \\
\text { training }\end{array}$ & 4.13 & 0.78 & 12.45036 & 117 & 0.00 \\
\hline Increased training of staff abroad & 3.31 & 1.09 & 2.427605 & 113 & 0.01 \\
\hline $\begin{array}{l}\text { Increased variety of methods } \\
\text { including on-the-job-e-trainings }\end{array}$ & 4.13 & 0.70 & 13.69632 & 119 & 0.00 \\
\hline $\begin{array}{l}\text { Increase acceptance of e-learning } \\
\text { training and certification }\end{array}$ & 3.74 & 0.87 & 7.318015 & 118 & 0.00 \\
\hline $\begin{array}{l}\text { Design of uniform training } \\
\text { programmes among the branches }\end{array}$ & 3.89 & 0.91 & 8.368775 & 118 & 0.00 \\
\hline Total & 3.78 & 0.70 & 6.048597 & 96 & 0.00 \\
\hline
\end{tabular}

\section{DISCUSSION OF FINDINGS}

Data presented in figures 1.1 and 1.5 with the result of testing of hypothesis 3 in Table 1 reveal that globalization has impacted on human resource training and development in several ways. In particular, results show that globalization has impacted on HR training and development in the following ways:

1. It has increased the frequency of training and development in most Nigerian organizations;

2. It has reduced the urge to go for staff training abroad;

3. Increased variety of methods including on-the-job-e-trainings;

4. Increase acceptance of e-learning training and certification;

5. It has led to the design of uniform training programmes among the branches of multinational organizations investigated;

This result agrees substantially with the findings of Chaykowski (2002) and Stilwell et al. (2004). Both studies agree that competition and advancements in information technology have fuelled the quest for higher skills. In particular, Stillwell et al (opcit and Ibid), found out that new communication technologies particularly internet has provided electronic access to education through distance learning. This result is quite interesting and has a lot of positive implications for the development of Nigerian organizations and economy. First, this development will reduce the tendencies where employees are caught in the dilemma of either giving up the idea of furthering their education because of their job or temporarily leaving their jobs for study leaves. For most employees, who do not have people to help them through school, they have had to stay at their jobs with limited education and thus income. With this new trend of increased on-the-job e- 
learning and acceptance of e-learning certifications, it is expected that this limitation to manpower development has been removed.

Second, this development will kick-start a change in the general belief that most African households do not invest in education because its private returns to that investment are not high enough to justify it (World Bank, 2000). With employees experiencing instant benefit of training either through promotion or change of job status, the perception that the benefits of education are limited will begin to change very drastically. Third, the design of uniform training programmes among multinational corporations for their staff world-wide may start opening up the possibility of the much expected and of course, desired technology transfer. These trainings and crosscountry postings all hold the possibility by Nigerian nationals who work in these organizations to acquire the much needed technology transfer. The other side of this result is that it also holds the possibility of exacerbating the phenomenon of 'brain drain'. Uniform training and cross-country postings all expose hitherto local staff to the opportunities in the global community and hence, increase the chances of his permanent move overseas.

Fourth, this finding means that the costs of manpower development for the Nigerian organizations and by extension the entire economy is generally lower. This is because has reduced the incidence of movement of staff overseas to acquire some specialized trainings, which are costlier in both nominal and opportunity cost terms.

\section{CONCLUSION}

This research effort sought to investigate the impact of globalization on human resources training and development among employees in Nigerian firms. The underlying theoretical assumptions for this study are: that globalization as a world-wide phenomenon has come to stay and has far reaching implications in almost all spheres of life; that the competitive cutting edge of Nigeria in a globalized world are the knowledge profile of its human resources; it therefore makes academic sense to examine the relationship between the two.

This study findings show that globalization has impacted positively on human resources training and development. In particular, findings show that globalization has increased the frequency and methods of trainings, increased use and acceptance of e-trainings and certification and uniform design of training programmes across the subsidiaries of MNCs globally. All these were found to reduce the physical incidence of personnel going abroad to study.

Funding: This study received no specific financial support.

Competing Interests: The authors declare that they have no competing interests.

Contributors/Acknowledgement: All authors contributed equally to the conception and design of the study.

\section{REFERENCES}

Adei, S., 2004. Impact of Globalisation on Management the African Perspective, Management in Nigeria, 39/40. 
Aimiuwu, l.E.A., 2004. Globalisation- The Human Resource Challenge, Management in Nigeria, 39/40.

Appelbaum, E. and R. Batt, 1994. The new american workplace: Transforming work systems in the united states. Ithaca: ILR Press.

Bae, J. and C. Rowley, 2002. The impact of globalisation on HRM. Journal of World Business Review, 36(4):402-428.

Bartram, D., 2011. Economic migration and happiness: Comparing immigrants' and natives' happiness gains from income. Soc Indic Res, 103(1): 57-76.

Bernardine, H.J., 2003. Human resources management an experiential approach. Third Edition Edn., New York: MacGraw- Hill Inc.

Bird, A., S. Taylor and S. Beechler, 1998. A typology of human resource management in japanese multinational corporations: Organizational implications, Human Resources Management, 37(2): 159-172.

Boateng, F.O. and P.K. Oppon-Boakye, 2013. Remittances from abroad: The ghanaian household perspective. International Journal of Business and Social Science, 4(1): $164-170$.

CBN, C.B.o.N., 2007. Remittances environment in Nigeria, an unpublished report by the Research and Statistics Department, CBN, Abuja, Nigeria.

Chaykowski, R.P., 2002. Globalisation and canadian labour policy, Canadian Public Policy, 28(1): 81-91.

Dasgupta, K., 2009. Learning, knowledge diffusion and the gains from globalisation, seminar paper presented to at the university of toronto, in november

Farazmand, A., 1999. Globalization and public administration. Public Administration Review, 59(6): 509-522.

Harnendez-Coss, R. and C.E. Bun, 2007. The UK-Nigerian Remittances Corridor: Challenges of Embracing Formal Transfer Systems in a Dual Financial Environment, The World Bank Working Paper 92.

Herstad, S.J. and T. Brekke, 2011. Globalisation, Modes of Innovation and Regional Innovation systems, Paper presented at the 5th International Seminar on Regional Innovation Policies, October 14th -15 th Grimstand, Norway.

Kale, D. and S. Little, 2010. Globalization, migration and knowledge transfer: The reconfiguration of $r \& d$ capability in indian pharmaceutical firms. New Delhi: Sage.

Khor, M., 2003. Globalization and the south, some critical issues. Ibadan: Spectrum Books Limited.

Lindely, A., 2008. African remittances and progress: Opportunities and challenges. Department of International Development, University of Oxford.

Lipsey, R., 1993. Globalisation, technological change, and economic change. Canadian Business Economics, 2(1). 
Locke, J.R. and T. Kochan, 1995. Conclusion: The transformation of Industrial revolution.

Ohamae, K., 1990. The borderless world. New York: Harper Business.

Orozco, M. and B. Mills, 2008. Remittances competition and fair finance access opportunities in nigeria. Document produced for review by USAID, Washington D.C.

Rivera, J.P.R. and P.O. Reyes, 2011. Remittances as avenue for encouraging household entrepreneurial activities. Journal of International Business Research, 10(3): 85113.

Robles, V.F. and R.S. Oropesa, 2011. International migration and the education of children: Evidence from lima peru. Population Research Policy Review, 30(4): 591-618.

Rodney, W., 1972. How europe underdeveloped Africa. Abuja: Panaf Publishing Incorporation.

Soludo, C.C., 2008. Financial globalisation and domestic monetary policy: Whither the economics for the 21 st century? 40th Inaugural lecture of the University of Nigeria.

Steers, R.M. and L. Nardon, 2006. Managing in the global economy. New Delhi: Prentice-Hall of India Private limited.

Stiglitz, J.E., 2003. Globalization and its discontents. New York: WW Northon and Company Incorporation.

Stilwell, B., D. Khassoum, P. Zurn, M. Vujicic, O. Adams and M. Dal Poz, 2004. Migration of health workers from developing Countries: strategic approaches to its management, Bulletin of World health organization, 82(8):595-600.

Thurow, L., 1992. Head to head. New York: William Morrow.

Wolfensohn, J.D., 2002. Opening address, annual world bank conference on development economics 2001/2002. New York: Oxford University Press.

World Bank, 2000. Can Africa Claim The 21st Century? Washington D.C: The International Bank for Reconstruction and Development.

World Bank, 2011. Remittances data, Development Prospects Group, Vanguard Newspaper.

World Bank, a.I.F.C., 2008. Doing business in nigeria. NW: The International Bank for Reconstruction and Development/World Bank.

World Bank Doing Business in Nigeria, 2008. Nw: The international bank for reconstruction and development/world bank. 